\title{
Metabolic implications of ammonia production in the ruminant
}

\author{
BY D. S. PARKER ${ }^{1}, M . A . \operatorname{LOMAX}^{2}$, C. J. SEAL ${ }^{1}$ \\ AND J. C. WILTON ${ }^{3}$ \\ ${ }^{1}$ Department of Biological and Nutritional Sciences, University of Newcastle upon Tyne, \\ Newcastle upon Tyne NE1 7RU \\ ${ }^{2}$ School of Animal and Microbial Sciences, University of Reading, Whiteknights, Reading RG6 $2 A J$ \\ ${ }^{3}$ School of Biochemistry, University of Birmingham, Edgbaston, Birmingham B15 2TT
}

$\mathrm{NH}_{3}$ is generated in the gut of all animal species as a result of two main processes: (1) microbial degradation of nitrogenous compounds such as proteins, peptides, amino acids and nucleic acids within the gut lumen and (2) microbial hydrolysis of urea passing across the gut wall from the blood and interstitial fluids. Whereas in most species the production of $\mathrm{NH}_{3}$ and its incorporation into microbial protein in the hindgut is considered of little nutritional benefit to the host (apart from coprophagic species), the pathway of $\mathrm{N}$ assimilation into microbial protein in the reticulo-rumen is an essential component of protein flow to the small intestine of ruminant animals. As such it has been demonstrated that ruminants can sustain a modest level of productivity when provided only with non-protein-N in the diet (Virtanen, 1969). Protein rationing for this group of livestock is based on provision of rumen-degradable $\mathrm{N}$ for microbial protein synthesis in addition to an undegradable component calculated to support required levels of output (Agricultural Research Council, 1980, 1984; Agricultural and Food Research Council, 1993). It is not the purpose of the present review, however, to evaluate rumen $\mathrm{N}$ transactions but to identify the pathways by which $\mathrm{NH}_{3}$ is generated within the gut and factors which affect its absorption and detoxification in the liver. There are a number of excellent reviews which discuss the broader aspects of $\mathrm{N}$ metabolism in the ruminant (MacRae \& Reeds, 1980; Chalupa, 1984; Egan et al. 1986; Lobley, 1991).

\section{RUMEN AMMONIA TURNOVER}

The primary sources of $\mathrm{NH}_{3}$ within the rumen are the protein components of the diet. Protein degradability is dependent on a number of factors including solubility, susceptibility to microbial proteases and residence time in the rumen (Taminga, 1983). These factors combine to produce a pattern of release of peptides, amino acids and $\mathrm{NH}_{3}$, all of which provide a source of $\mathrm{N}$ for microbial protein synthesis. The extent to which the range of microbial species within the rumen are able to utilize these different sources is a matter of debate. Although early work (Bryant \& Robinson, 1962) indicated that about $90 \%$ of bacterial species isolated from the rumen could utilize $\mathrm{NH}_{3}$ as the main source of $\mathrm{N}$ for growth, further studies have demonstrated a potential for free amino acids and peptides to become incorporated into microbial protein without passing through the rumen $\mathrm{NH}_{3}$ pool (Cotta \& Hespell, 1986; MacKie \& White, 1990). More recent studies using ${ }^{15} \mathrm{NH}_{3}$ to quantify uptake of protein degradation products for microbial protein synthesis have also shown that for a range of feed protein sources a maximum of $0 \cdot 4-0.68$ of microbial $\mathrm{N}$ was derived from the rumen $\mathrm{NH}_{3}$ pool (Hristov \& Broderick, 1994).

Our understanding of the extent of the flux of $\mathrm{NH}_{3}$ within the rumen is based on 


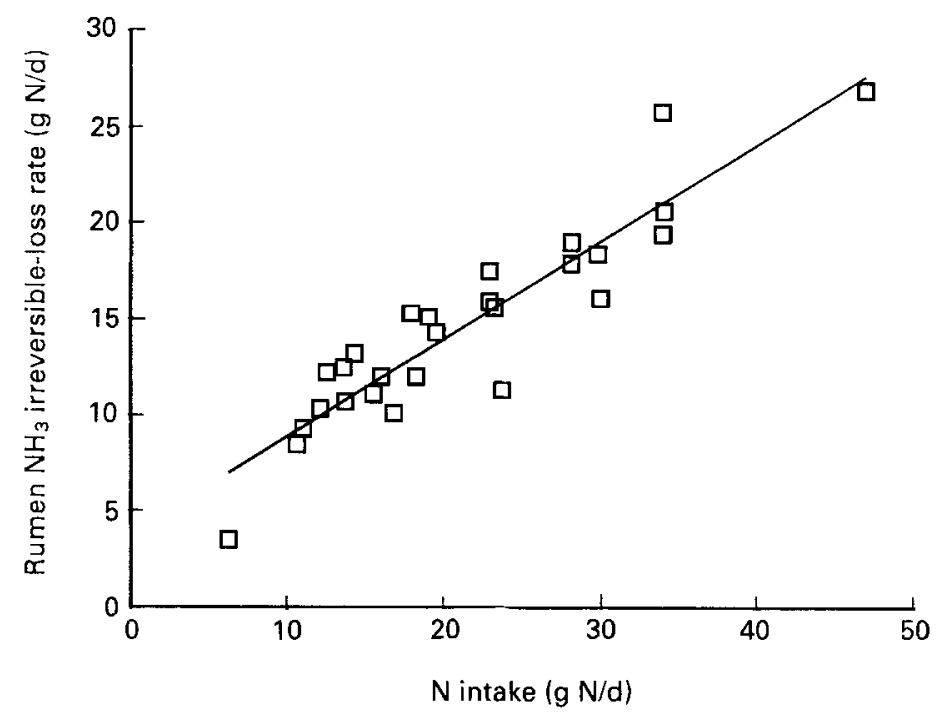

Fig. 1. The relationship between rumen ammonia irreversible-loss rate $(\mathrm{gN} / \mathrm{d})$ and $\mathrm{N}$ intake (gN/d). Each point represents animal means from individual experiments. The equation of the regression line is $y=3 \cdot 829+0 \cdot 507 x$ $\left(r^{2}\right.$ 0.853). Data are from the experiments of Pilgrim et al. (1970); Mathison \& Milligan (1971); Nolan et al. (1976); Nolan \& MacRae (1976); Kennedy \& Milligan (1978); Nolan \& Strachin (1979); Siddons et al. (1985b) and Kennedy et al. (1986).

extensive use of ${ }^{15} \mathrm{~N}$-tracer methodology developed to study $\mathrm{N}$ transactions within the gut, and between the gut and peripheral blood in sheep (Mathison \& Milligan, 1971; Nolan, 1975; Nolan et al. 1976; Siddons et al. 1985a; Kennedy et al. 1986). These turnover studies have identified the relationship between $\mathrm{N}$ intake in the diet and $\mathrm{NH}_{3}$ irreversible-loss rates over a wide range of $\mathrm{N}$ source and level in the diet (Fig. 1). These findings indicate that 0.5 of dietary $\mathrm{N}$ entering the rumen passes directly through the rumen $\mathrm{NH}_{3}$ pool which is somewhat higher than previously calculated $(0 \cdot 3$; Nolan, 1975). The difference reflects the availability of data from an increased number of trials carried out over a wider range of $\mathrm{N}$ intakes. Production of $\mathrm{NH}_{3}$ from endogenous sources within the rumen, calculated from the intercept of the regression line, has also changed from $4.4 \mathrm{~g} \mathrm{~N} / \mathrm{d}$ in the original study to $3.8 \mathrm{~g} \mathrm{~N} / \mathrm{d}$ when all the available data are included. This value represents primarily the flow of urea into the rumen via saliva and direct transfer across the rumen wall. Apart from incorporation into microbial protein, loss from this small $(0.5-1.5 \mathrm{~g} \mathrm{~N})$ but highly labile pool is either by absorption across the rumen wall or by passage out of the rumen in digesta flowing to the small intestine. Duodenal $\mathrm{NH}_{3}$ flow measured in cows (Firkins et al. 1987; Song \& Kennelly, 1990) and in sheep (MacRae et al. 1972; MacRae \& Ulyatt, 1974) represented 0.02 and 0.09 of $\mathrm{N}$ intake respectively. Of this, isotope-exchange studies suggest that about half $(0 \cdot 4-0 \cdot 6$; Siddons et al. $1985 b$ ) represents $\mathrm{NH}_{3}$ derived directly from the rumen $\mathrm{NH}_{3}$ pool. It is apparent, therefore, that the primary pathway of $\mathrm{NH}_{3}$ loss from the rumen is via absorption across the gut wall.

The dynamics of rumen $\mathrm{N}$ transactions measured using ${ }^{15} \mathrm{~N}$ isotope techniques provide important quantitative data relating feed $\mathrm{N}$ intake and the transfer of $\mathrm{N}$ between gut and 
body pools. This experimental approach is dependent on the establishment of steadystate conditions within the animal in order to measure nutrient flux in metabolite pools which, ideally, do not alter during the course of the experiment. In practice, however, $\mathrm{N}$ dynamics are dominated by cycles of nutrient release which are linked to patterns of intake and the physico-chemical characteristics of the feed. Numerous experiments have reported the effect of feeding either concentrate- or forage-based diets on rumen $\mathrm{NH}_{3}$ levels and the fluctuations in metabolite concentrations with time period after feeding (Wernli \& Wilkins, 1980). Silage feeding is an extreme example of this effect, the soluble nitrogenous components being rapidly degraded in the rumen to result in peaks of $\mathrm{NH}_{3}$ concentration of 18-20 mM within $1 \mathrm{~h}$ after feeding from a basal level of $2-4 \mathrm{mM}$. These levels can be attenuated by chemical treatment of the forage material before ensilage using acid-formaldehyde to reduce $\mathrm{N}$ solubility (Thompson et al. 1981) or by provision of a readily-fermentable carbohydrate to provide energy for $\mathrm{N}$ capture by the rumen microflora (Rooke et al. 1987). Rumen infusion studies in which either pulsed or continuous infusions of $\mathrm{N}$ and energy-yielding substrates have been used (Henning et al. 1993) demonstrate that providing a constant supply of energy may be a critical factor in improving nutrient utilization. In the absence of such provision, rapid fluctuations in $\mathrm{NH}_{3}$ concentration result in inefficient use of $\mathrm{N}$ for microbial protein synthesis and loss of $\mathrm{NH}_{3}$ from the rumen by absorption across the gut wall. In addition there may be periods during which rumen $\mathrm{NH}_{3}$ levels fall below those thought to be optimal for microbial growth; $3.5 \mathrm{mM}$ '(Satter \& Slyter, 1974) to $6 \mathrm{mM}$ (Kang-Meznarish \& Broderick, 1981), thereby reducing both energy and protein supply to the host animal. Synchronization of $\mathrm{N}$ and energy release within the rumen in order to maximize nutrient capture by the microbial population has been an objective of ruminant feeding systems. Recent experiments in sheep (Sinclair et al. 1993) in which diets were formulated on the basis of either asynchronous or synchronous release of nutrients have shown that manipulation of the pattern of substrate availability in this way can provide a practical method of improving the efficiency of $\mathrm{N}$ capture and reducing the magnitude of rumen $\mathrm{NH}_{3}$ cycling.

\section{MECHANISM OF INTESTINAL ABSORPTION OF AMMONIA}

The mechanisms involved in the bi-directional movement of $\mathrm{NH}_{3}$ across tissues of the gastrointestinal tract between the lumen and blood are not fully understood. Absorption does not appear to be active, but occurs by passive non-ionic diffusion down a concentration gradient. In ruminant animals the high concentrations of $\mathrm{NH}_{3}$ in rumen fluid favour the flux of $\mathrm{NH}_{3}$ into the bloodstream, but in small intestinal tissues there may be considerable movement of $\mathrm{NH}_{3}$ back into the intestinal lumen. Free $\mathrm{NH}_{3}$ diffuses readily across biological membranes because of its lipid solubility and lack of charge, in contrast to $\mathrm{NH}_{4}{ }^{+}$which as a hydrated, charged molecule has low lipid solubility and cannot diffuse across the cell membrane (Visek, 1969). The $\mathrm{pK}$ for the equilibrium between free $\mathrm{NH}_{3}$ and $\mathrm{NH}_{4}{ }^{+}$is approximately $9 \cdot 1$, thus under normal physiological conditions most of the $\mathrm{NH}_{3}$ present in the gut lumen ( $\mathrm{pH}$ range 2-6) will be in the ionized form. Diffusion of free $\mathrm{NH}_{3}$ across the rumen wall in the undissociated form has been demonstrated in vivo (Hogan, 1961; Siddons et al. 1985a; Bödeker et al. 1990; Rémond et al. 1993b) and in vitro (Mooney \& O'Donovan, 1970). Net $\mathrm{NH}_{3}$ flux across the rumen 
wall has been shown to be linearly correlated to both free $\mathrm{NH}_{3}$ (Siddons et al. 1985a) and to total $\mathrm{NH}_{3}$ concentrations (Rémond et al. 1993a) in rumen fluid, although it is thought that the free $\mathrm{NH}_{3}$ levels are more significant. Using the isolated rumen technique, however, Bödeker et al. (1990) showed that at a constant rumen $\mathrm{NH}_{3}$ concentration, $\mathrm{NH}_{3}$ absorption did not reflect the concentration ratio for undissociated:free $\mathrm{NH}_{3}$ in the artificial rumen fluid. These results suggest either a flux of $\mathrm{NH}_{3}$ molecules across the rumen wall or titration of $\mathrm{NH}_{4}{ }^{+}$at the absorptive surface. Further experiments by Bödeker et al. (1992b) have implicated volatile fatty acids (VFA) in this latter process. $\mathrm{NH}_{3}$ uptake was stimulated by the presence of VFA in the mucosal buffer solution either individually or as a mixture of acetate, propionate and butyrate. Similar responses to additional butyrate on transfer of $\mathrm{NH}_{3}$ into the ruminal vein of sheep have been reported by Rémond et al. (1993b). The mechanism involved is unclear, although the exchange of protons between the VFA and $\mathrm{NH}_{3}$ either at the cell surface and/or within the mucosa has been suggested. It is interesting that in rats fed on diets containing fermentable carbohydrates $\mathrm{NH}_{3}$ absorption from the caecum was increased (Rémésy \& Demigné, 1989). Although this may in part be due to the increased entry of urea into the caecum and its hydrolysis by the caecal flora, it is possible that the increased concentration of VFA in the caecal digesta also had a more direct effect on $\mathrm{NH}_{3}$ flux across the caecal wall.

The importance of bicarbonate in stimulating colonic $\mathrm{NH}_{3}$ absorption has been demonstrated in several studies in single-stomached animals (Wrong, 1978) and it is possible that similar mechanisms occur in the ruminant animal. Bödeker et al. (1992a), for example, have shown in vitro that inhibition of carbonic anhydrase (which would result in a lowering of free bicarbonate ions) caused a reduction in $\mathrm{NH}_{3}$ flux across the rumen wall. In this experiment addition of VFA to the mucosal incubation solution restored $\mathrm{NH}_{3}$ flux to control levels suggesting that bicarbonate and VFA may play similar roles in mediating $\mathrm{NH}_{3}$ uptake. Increasing $\mathrm{HCO}_{3}$ - levels in rumen fluid by bubbling $\mathrm{CO}_{2}$ into the rumen also caused an increase in $\mathrm{NH}_{3}$ flux in sheep (Rémond et al. 1993b) although it is not clear whether this was a direct effect on transfer across the ruminal epithelium or increasing ruminal vein blood flow.

\section{AMMONIA ABSORPTION INTO PORTAL BLOOD}

As a consequence of the extensive turnover of $\mathrm{N}$-containing compounds in the digestive tract of ruminants and the loss of $\mathrm{NH}_{3}$ across the gut wall a significant proportion of dietary $\mathrm{N}$ intake can be measured as $\mathrm{NH}_{3}$ flux in portal blood. The relationship between these two variables has been examined recently (Seal \& Reynolds, 1993) for a wide range of diets and these authors confirm previous observations that portal $\mathrm{NH}_{3}$ flux can represent as much as 0.65 of $\mathrm{N}$ intake and in many circumstances exceed net $\alpha-\mathrm{NH}_{2}-\mathrm{N}$ absorption into portal blood. Similar calculations for single-stomached species are hampered by the lack of quantitative information concerning arterio-venous blood concentrations across the gut and measurements of blood flow. There are, however, a number of studies in pigs in which between 0.14 and 0.24 of daily $\mathrm{N}$ intake can be accounted for in the measured flux of $\mathrm{NH}_{3}$ in portal blood (Malmlöf, 1987; van Berlo et al. 1988; Yen \& Pond, 1990; Yen \& Nienaber, 1993). Detoxification of absorbed $\mathrm{NH}_{3}$ by urea cycle activity in the liver is common to all species and calculation of portal $\mathrm{NH}_{3}$ flux on a metabolic-weight $\left(\mathrm{W}^{0 \cdot 75}\right)$ basis provides a mechanism of 'scaling' the effects of 
Table 1. Net portal ammonia absorption in different species

\begin{tabular}{|c|c|c|c|c|}
\hline Species & $\begin{array}{l}\text { Portal } \mathrm{NH}_{3} \\
\quad(\mu \mathrm{M})\end{array}$ & $\begin{array}{l}\text { Arterial } \mathrm{NH}_{3} \\
\quad(\mu \mathrm{M})\end{array}$ & $\begin{array}{l}\text { Net absorption } \\
(\mu \mathrm{mol} / \mathrm{min} \\
\left.\text { per } \mathrm{kgW}^{0.75}\right)\end{array}$ & Reference \\
\hline Rat & 193 & 72 & $2 \cdot 8$ & Hartman \& Prior (1992) \\
\hline Pig & $\begin{array}{l}285 \\
165 \\
205\end{array}$ & $\begin{array}{r}142 \\
44 \\
39\end{array}$ & $\begin{array}{r}14 \cdot 3 \\
17 \cdot 9 \\
8 \cdot 2\end{array}$ & $\begin{array}{l}\text { Malmlöf (1987) } \\
\text { van Berlo et al. }(1988) \\
\text { Yen \& Pond (1990) }\end{array}$ \\
\hline Sheep: Fed & 487 & 210 & $33 \cdot 2$ & Gross et al. (1990) \\
\hline $\begin{array}{l}\text { Intragastric } \\
\text { infusion }\end{array}$ & 377 & 200 & $19 \cdot 5$ & Gross et al. (1990) \\
\hline Steers & 560 & 220 & $35 \cdot 2$ & Harmon et al. (1988) \\
\hline Cows (lactating) & 650 & 350 & $71 \cdot 5$ & Huntington (1984) \\
\hline $\begin{array}{r}\text { Steers }(2 \times \text { daily fed): } \operatorname{Min} \\
\text { Max }\end{array}$ & $\begin{array}{l}356 \\
525\end{array}$ & $\begin{array}{l}122 \\
112\end{array}$ & $\begin{array}{l}44 \cdot 2 \\
82 \cdot 1\end{array}$ & $\begin{array}{l}\text { Wilton (1989) } \\
\text { Wilton }(1989)\end{array}$ \\
\hline
\end{tabular}

differences in the digestion of dietary $\mathrm{N}$ between ruminant and non-ruminant species. The results of this calculation are shown in Table 1. It is apparent that for both rats and pigs the mean value of $11 \mu \mathrm{mol} / \mathrm{min}$ per $\mathrm{kgW}^{0.75}$ is significantly lower than that for ruminants of between 20 and $75 \mu \mathrm{mol} / \mathrm{min}$ per $\mathrm{kgW}^{0.75}$ dependent on the diet and pattern of feeding. Where measurements have been made over a period of time it is also apparent that flux rates are reasonably constant in pigs relative to the time interval after feeding (Yen \& Nienaber, 1993), whereas in ruminants fed twice daily, rather than continuously as in most of the nutrient absorption studies, portal flux rates can virtually double between prefeeding and $90 \mathrm{~min}$ post-feeding $\left(44-82 \mu \mathrm{mol} / \mathrm{min}\right.$ per $\mathrm{kgW}^{0.75}$; Wilton, 1989).

Although portal absorption rates provide an overall measure of $\mathrm{NH}_{3}$ flux into the blood pool, a number of different techniques have been used to study the relative contribution of different sections of the digestive tract to total $\mathrm{NH}_{3}$ absorption. Studies of digesta flow in sheep (MacRae \& Ulyatt, 1974) showed that some 0.15 of $\mathrm{N}$ intake was absorbed as $\mathrm{NH}_{3}$ in the small intestine and application of ${ }^{15} \mathrm{~N}$ techniques provided a dynamic model of $\mathrm{NH}_{3}-\mathrm{N}$ movement across different sections of the tract (Siddons et al. 1985a). This latter study indicated that in sheep fed on a silage diet 0.25 of total $\mathrm{NH}_{3}$ absorption occurred across small intestinal tissues. This proportion was increased to $0 \cdot 37$ when the sheep were fed on a diet consisting of dried grass. These values confirm measurements made in chronically-catheterized animals in which $\mathrm{NH}_{3}$ flux into blood vessels draining the small intestine (mesenteric vein) has been compared with total uptake into the portal vein which includes absorption from both the rumen-reticulumomasum and the large intestine. These studies are summarized in Table 2 and show that between 0.25 and 0.41 of portal $\mathrm{NH}_{3}$ flux is attributable to absorption from the small intestine. The importance of this section of the digestive tract in the cycling of $\mathrm{N}$ in this way is underlined by the experiments of Gross et al. (1990) in which they maintained sheep by intragastric infusion of nutrients but with the protein component of the diet infused directly into the abomasum. Portal $\mathrm{NH}_{3}$ flux in these animals was $20 \mu \mathrm{mol} / \mathrm{min}$ per $\mathrm{kgW}^{0.75}$ during the infusion periods compared with $33 \mu \mathrm{mol} / \mathrm{min}$ per $\mathrm{kgW}^{0.75}$ when the animals were fed on lucerne (Medicago sativa). 
Table 2. Contribution of ammonia absorption from the small intestine to total net uptake into the portal vein in steers

\begin{tabular}{|c|c|c|c|c|}
\hline \multirow[b]{2}{*}{ Diet } & \multicolumn{2}{|c|}{$\begin{array}{c}\mathrm{Net}^{\mathrm{NH}_{3} \text { uptake }} \\
\left(\mu \mathrm{mol} / \mathrm{min} \text { per } \mathrm{kgW}^{0.75}\right)\end{array}$} & \multirow{2}{*}{$\begin{array}{l}\text { Mesenteric } \\
\text { absorption as } \\
\text { proportion } \\
\text { of total }\end{array}$} & \multirow[b]{2}{*}{ Reference } \\
\hline & $\begin{array}{l}\text { Mesenteric } \\
\text { vein }\end{array}$ & $\begin{array}{l}\text { Portal } \\
\text { vein }\end{array}$ & & \\
\hline Grass nuts & $15 \cdot 8$ & $42 \cdot 4$ & $0 \cdot 37$ & Seal et al. (1992) \\
\hline \multicolumn{4}{|l|}{ Grass nuts-flaked maize } & \\
\hline $\begin{array}{l}\text { Grass nuts-intraruminal } \\
\text { propionate }\end{array}$ & $6 \cdot 7$ & $23 \cdot 15$ & 0.29 & $\begin{array}{l}\text { Seal \& Parker } \\
\quad \text { (unpublished results) }\end{array}$ \\
\hline \multicolumn{5}{|l|}{ Lucerne (Medicago sativa): } \\
\hline Time-fed & $13 \cdot 12$ & $46 \cdot 0$ & 0.28 & Reynolds \& Huntington \\
\hline Meal-fed & $17 \cdot 62$ & $64 \cdot 68$ & 0.27 & (1988) \\
\hline Concentrates (meal-fed) & $14 \cdot 31$ & $28 \cdot 25$ & 0.51 & \\
\hline
\end{tabular}

$\mathrm{W}^{0.75}$, metabolic weight.

\section{HEPATIC DETOXIFICATION OF AMMONIA}

Under normal physiological and nutritional conditions, $\mathrm{NH}_{3}$ absorbed into the portal vein is efficiently extracted by the liver and detoxified by conversion to urea or glutamine. Over a wide range of portal $\mathrm{NH}_{3}$ concentrations on a variety of different diets, the liver is able to extract $70-95 \%$ of portal $\mathrm{NH}_{3}$ with the result that hepatic $\mathrm{NH}_{3}$ removal is on average very slightly higher $(4 \%)$ than portal absorption (Table 3 ). This results in arterial $\mathrm{NH}_{3}$ concentrations remaining constant even when portal $\mathrm{NH}_{3}$ absorption varies threefold. $\mathrm{NH}_{3}$ is extremely toxic in non-hepatic tissues and causes changes in cerebral metabolism which result in tetany and death when circulating $\mathrm{NH}_{3}$ concentrations exceed $0.7 \mathrm{mM}$ (Symonds et al. 1981). Ruminants are susceptible to diet-induced $\mathrm{NH}_{3}$ toxicity particularly when non-protein- $\mathrm{N}$ is rapidly converted to $\mathrm{NH}_{3}$ in the rumen and absorbed into the portal vein (Visek, 1984). Most investigators have reported arterial $\mathrm{NH}_{3}$ concentrations in the $0.1 \mathrm{mM}$ range using a specific enzyme assay which follows the reaction with glutamate dehydrogenase (EC 1.4.1.2; Bergmeyer \& Beutler, 1985). A number of estimates of circulating $\mathrm{NH}_{3}$ concentration, however, have employed the Berthelot reaction (McCullough, 1967) which gives values of 300-400 $\mu \mathrm{M}$ (Huntington, 1989; Reynolds et al. 1991; see also Table 1) due to non-specific reactions, although these overestimated values do not appear to affect the values for net $\mathrm{NH}_{3}$ exchange across tissues (L. A. Crompton and C. K. Reynolds, personal communication).

A functional heterogeneity of metabolism, particularly of carbohydrates and $\mathrm{N}$ has been established in rat liver parenchymal cells (Jungermann, 1986). This ensures that any $\mathrm{NH}_{3}$ which escapes conversion to urea in periportal hepatocytes is converted to glutamine in perivenous hepatocytes. The amide- $\mathrm{N}$ of glutamine is then removed and metabolized to urea by periportal hepatocytes during subsequent passages through the liver and may also provide a mechanism to prevent a decrease in extracellular $\mathrm{pH}$ (Haussinger et al. 1992). In ruminants, there is net hepatic uptake of glutamine and 
N TRANSACTIONS IN THE GUT

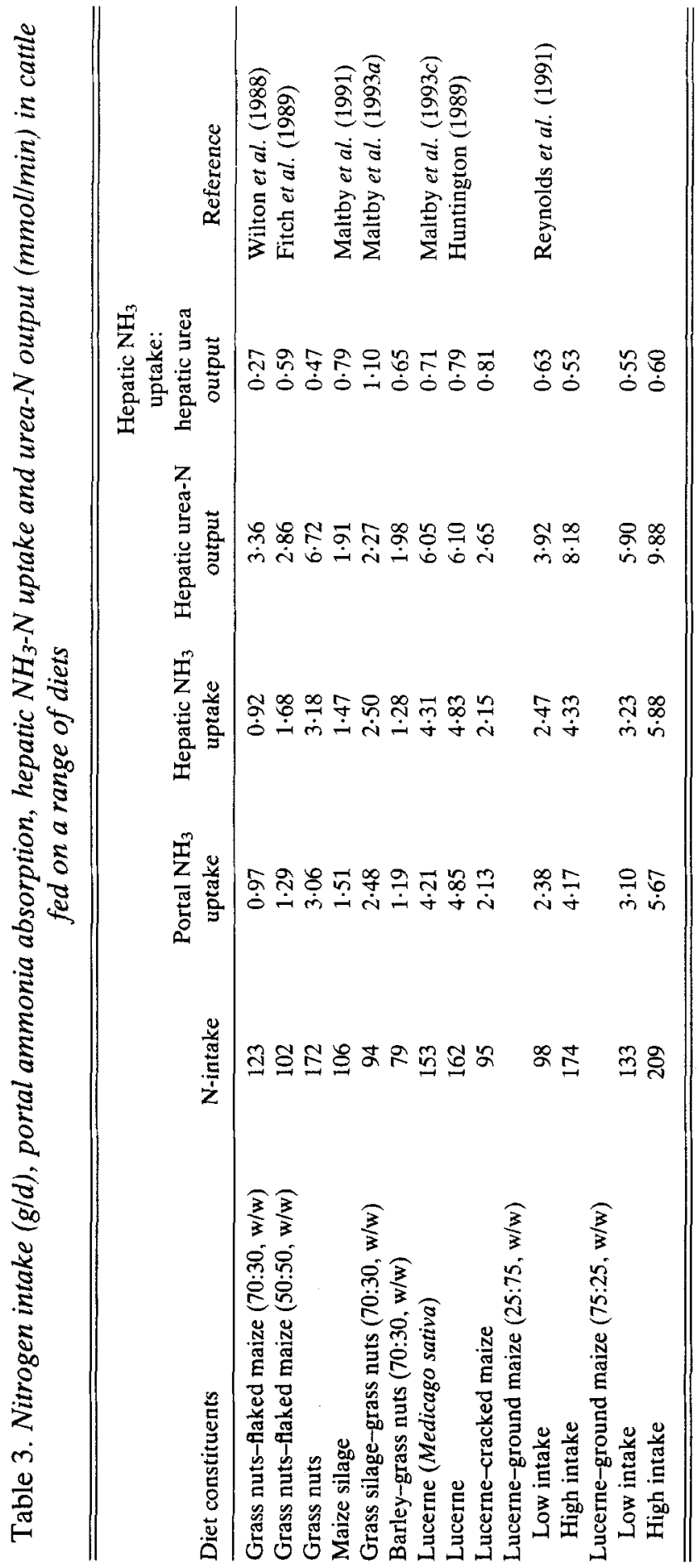


output of glutamate (Wolff et al. 1972; Reynolds, 1992) which is in agreement with the hepatic intracellular cycle proposed. When urea is added to ruminant diets there is increased hepatic uptake of $\mathrm{NH}_{3}$ but glutamine uptake is either unchanged or slightly increased whilst net hepatic glutamate output is decreased (Maltby et al. 1991, 1993b). However, these changes in amino acid flux are small and the increase in hepatic urea synthesis can more than account for $\mathrm{NH}_{3}$ removal, suggesting that conversion of $\mathrm{NH}_{3}$ to glutamine or glutamate is not a major detoxification pathway under normal feeding conditions. This has recently been confirmed by an in vivo study in sheep which demonstrated that 93.5 and $6 \%$ respectively of portal ${ }^{15} \mathrm{NH}_{4} \mathrm{Cl}$ is converted to [ ${ }^{15} \mathrm{~N}$ ] urea and $\left[{ }^{15} \mathrm{~N}\right]$ glutamine when portal vein $\mathrm{NH}_{3}$ concentrations are increased to $0.5 \mathrm{mM}$ by intramesenteric vein infusion (Lobley et al. 1995). The upper limit to the capacity of ruminant liver to remove $\mathrm{NH}_{3}$ is $1.2-1.5 \mu \mathrm{mol} / \mathrm{min}$ per $\mathrm{g}$ (Linzell et al. 1971; Symonds et al. 1981; Orzechowski et al. 1987), which compares with a range of $0.2-0.8 \mu \mathrm{mol} / \mathrm{min}$ per $g$ over a wide variety of nutritional regimens. Therefore, the capacity of ruminant hepatocytes to detoxify $\mathrm{NH}_{3}$ directly to urea appears to be well adapted to large changes in portal $\mathrm{NH}_{3}$ concentration and is only exceeded when $\mathrm{NH}_{3}$ loads on the liver are abnormal (Symonds et al. 1981; Fernandez et al. 1990).

\section{CONTRIBUTION OF AMMONIA TO HEPATIC UREA SYNTHESIS}

In addition to the relationship between $\mathrm{N}$ intake and portal $\mathrm{NH}_{3}$ absorption (see p. 552), data in Table 3 show that hepatic $\mathrm{NH}_{3}$ uptake is positively correlated with $\mathrm{N}$ intake and accounts for between 16 and $60 \%$ of $\mathrm{N}$ intake.

$$
\mathrm{N} \text { intake }(\mathrm{g} / \mathrm{d})=64 \cdot 5+22 \cdot 5 \text { hepatic } \mathrm{NH}_{3} \text { uptake }(\mathrm{mmol} / \mathrm{min})\left(r^{2} 0 \cdot 74\right) \text {. }
$$

The potential contribution of extracted $\mathrm{NH}_{3}-\mathrm{N}$ to hepatic urea- $\mathrm{N}$ formation ranges from 27 to $110 \%$. This value compares with an estimated contribution of $33 \%$ of urea flux from portal $\mathrm{NH}_{3}$ in humans and rodents (Meijer et al. 1990). The reason for the variation in the apparent contribution of $\mathrm{NH}_{3}$ to hepatic urea production is not clear; the values in Table 3 have been obtained from different laboratories and using various techniques for measuring $\mathrm{NH}_{3}$ and urea, suggesting that the large range is not an artefact and animal factors such as breed or $\mathrm{N}$ quality and intake appear not to be implicated. Dietary differences may be relevant since low values for $\mathrm{NH}_{3}$ contribution to hepatic urea output have been reported for beef cattle fed on mixtures of dried grass nuts and flaked maize, while high values have been associated with diets based on lucerne hay-maize, grass silage-barley or maize silage (Table 3). There are inconsistencies within this pattern, however, and the results may represent the limitations of the arterio-venous difference techniques to establish stoichiometric relationships across an organ. The proportion of urea- $\mathrm{N}$ apparently accounted for by hepatic $\alpha-\mathrm{NH}_{2}-\mathrm{N}$ removal ranges from 16 to $30 \%$ (Huntington, 1989; Reynolds et al. 1991), although these estimates are based on measurement of $\alpha-\mathrm{NH}_{2}-\mathrm{N}$ rather than a summation of individual amino acids separated by ion-exchange chromatography. A recent comparison of the two methods suggests that they give approximately similar values (Maltby et al. 1993a).

\section{IMPACT OF AMMONIA ON HEPATIC AMINO ACID METABOLISM}

Wilton et al. (1988) imposed an acute $\left(3 \mathrm{~h}\right.$ ) hepatic $\mathrm{NH}_{3}$ load in beef cattle by infusion of $\mathrm{NH}_{4} \mathrm{Cl}$ into a mesenteric vein and observed that the increase in hepatic urea- $\mathrm{N}$ 
production was three times greater than that in the rate of $\mathrm{NH}_{3}-\mathrm{N}$ removed by the liver. The findings suggested that the urea synthesis from non- $\mathrm{NH}_{3}$ sources had been stimulated during $\mathrm{NH}_{3}$ load and were supported by a trend for increased free amino acid uptake. The findings of this study agreed with those of a similar experiment in sheep (Orzechowski et al. 1987), although in both reports the results could be explained by incomplete recovery in the portal vein of infused $\mathrm{NH}_{3}$. Lobley et al. (1995) have confirmed recently in sheep that a $5 \mathrm{~d}$ intramesenteric vein infusion of $\mathrm{NH}_{3}$ increases hepatic urea production to approximately double that predicted from stoichiometric conversion of $\mathrm{NH}_{3}$ removed to urea. These findings could help to explain the inefficient retention of absorbed amino acids in forage-fed ruminants, since amino acid deamination may be increased as a result of the increased hepatic uptake of $\mathrm{NH}_{3}$ observed with forage-based diets (Fitch et al. 1989; Huntington, 1989; Reynolds et al. 1991). Other studies have altered $\mathrm{NH}_{3}$ supply to the liver by changing diet composition or level of intake: Fitch et al. (1989) and Huntington (1989) compared forage and cereal diets fed to cattle (Table 3) and demonstrated that the forage-based diet doubled both hepatic $\mathrm{NH}_{3}$ uptake and the proportion of urea- $\mathrm{N}$ output that was apparently synthesized from non- $\mathrm{NH}_{3}-\mathrm{N}$ sources. Huntington (1989) demonstrated that hepatic $\alpha-\mathrm{NH}_{2}-\mathrm{N}$ removal was stimulated twofold on the forage diet with the result that total splanchnic supply of $\alpha-\mathrm{NH}_{2}-\mathrm{N}$ to peripheral tissues was decreased by $30 \%$. Regression of hepatic $\mathrm{NH}_{3}$ uptake $v$. urea production using the values in Table 3 yields a significant positive correlation.

Hepatic $\mathrm{NH}_{3}$ uptake $(\mathrm{mmol} / \mathrm{min})=0.43+0.53$ hepatic urea- $\mathrm{N}$ output $(\mathrm{mmol} / \mathrm{min})$ $\left(r^{2} 0 \cdot 80\right)$.

The slope of this line suggests that an increase in hepatic $\mathrm{NH}_{3}$ uptake is associated with twice as much urea production as that predicted from direct $\mathrm{NH}_{3}$ detoxification. When $\mathrm{N}$ intake is regressed $v$. the values for hepatic urea- $\mathrm{N}$ output in Table 3 , the equation predicts that as $\mathrm{N}$ intake increases there is a proportionately greater increase in hepatic urea-N synthesis.

$\mathrm{N}$ intake $(\mathrm{g} / \mathrm{d})=60 \cdot 2+14 \cdot 8$ hepatic urea-N output $(\mathrm{mmol} / \mathrm{min})\left(r^{2} 0 \cdot 92\right)$.

Whilst it is possible that these relationships reflect the increasing supply of amino acids to the liver, they support the suggestion that an increased $\mathrm{NH}_{3}$ load on the liver has a cost of detoxification in relation to amino acid catabolism which would be of considerable significance to growth (muscle deposition) in silage-fed animals.

\section{MECHANISM FOR THE INTERRELATIONSHIP BETWEEN AMMONIA AND HEPATIC AMINO ACID METABOLISM}

The synthesis of urea involves the assimilation of two $\mathrm{N}$ atoms, one from $\mathrm{NH}_{3}$ via mitochondrial carbamoylphosphate synthesis and the other from cytoplasmic aspartate. Mitochondrial and cytosolic aspartate-glutamate transamination pools are thought to be in equilibrium (Cooper et al. 1991), with the result that $\mathrm{N}$ from $\mathrm{NH}_{3}$ or amino acids can contribute both $\mathrm{N}$ atoms of the urea molecule via the reversible action of glutamate dehydrogenase (Meijer et al. 1990). The in vivo studies discussed previously have led us to suggest, however, that under conditions of high urea flux, the mitochondrial supply of $\mathrm{NH}_{3}$ may not be able to supply both $\mathrm{N}$ moieties of urea, with the result that amino acid-N is transferred to urea. This would effectively induce an amino acid deamination 'cost' for 
$\mathrm{NH}_{3}$ detoxification. Strong evidence in support of this proposal has recently been obtained by the use of isotopomer analysis to examine the contribution of $\mathrm{NH}_{3}$ to the two $\mathrm{N}$ moieties of urea by measuring the flux of ${ }^{15} \mathrm{NH}_{4} \mathrm{Cl}$ into $\left[{ }^{14} \mathrm{~N},{ }^{15} \mathrm{~N}\right]-$ and $\left[{ }^{15} \mathrm{~N},{ }^{15} \mathrm{~N}\right]$ urea: after $5 \mathrm{~d}$ of an infusion of $\mathrm{NH}_{3}$ into the mesenteric vein of sheep, at least $97 \%$ of the $\left[{ }^{15} \mathrm{~N}\right]$ urea molecules formed were as $\left[{ }^{14} \mathrm{~N},{ }^{15} \mathrm{~N}\right] \mathrm{urea}$ and the amounts of $\left[{ }^{15} \mathrm{~N},{ }^{15} \mathrm{~N}\right] \mathrm{urea}$ were close to the detection limits (Lobley et al. 1995). In the same study an increase in leucine oxidation was noted, supporting the concept of increased requirement of $\alpha-\mathrm{NH}_{2}-\mathrm{N}$ for urea synthesis during $\mathrm{NH}_{3}$ detoxification. This evidence, that there is a ' $\mathrm{NH}_{3}$ detoxification cost' in terms of hepatic amino acid deamination, may not be exclusive to ruminants since ingestion of ${ }^{15} \mathrm{NH}_{4} \mathrm{Cl}$ by fed and fasted humans is followed by the appearance of the majority of the label in $\left[{ }^{14} \mathrm{~N},{ }^{15} \mathrm{~N}\right]$ urea (Weijs et al. 1995).

The specific intracellular mechanism responsible for the proposed interaction between $\mathrm{NH}_{3}$ and amino acid deamination is still unclear. Recent studies in fasted sheep hepatocytes (Luo et al. 1995) have demonstrated that when ${ }^{15} \mathrm{NH}_{4} \mathrm{Cl}$ is the only $\mathrm{N}$ source in the incubation, $\left[{ }^{15} \mathrm{~N},{ }^{15} \mathrm{~N}\right]$ urea is the predominant form of urea suggesting that pathways of $\mathrm{NH}_{3}$ conversion to urea in ruminants are similar to those of rodents. Addition of a physiological mixture of unlabelled amino acids to hepatocyte incubations increased the rate of $\left[{ }^{14} \mathrm{~N}^{15} \mathrm{~N}\right]$ urea appearance, but this did not increase with higher rates of $\mathrm{NH}_{3}$ detoxification as would be predicted from the in vivo results of Lobley et al. (1995).

Krebs et al. (1979) suggested that increased amino acid utilization with increased ureagenesis may be the result of competition between gluconeogenic and ureagenic pathways for cytoplasmic oxaloacetate. Gluconeogenesis is a major synthetic pathway in fed ruminant liver and $\mathrm{NH}_{3}$ has been demonstrated to inhibit glucose synthesis by ovine hepatocytes (Weekes et al. 1978; Aiello \& Armentano, 1987; Demigné et al. 1991) and urea feeding to calves has been shown to decrease glucose disposal rates (Spires \& Clark, 1979). The experiments of Wilton et al. (1988) and Maltby et al. (1991, 1993a), however, have failed to confirm this effect in vivo since net hepatic glucose release is not altered either by mesenteric vein $\mathrm{NH}_{3}$ infusion or by feeding urea to calves. Furthermore, altering the media concentration of propionate, the major gluconeogenic substrate in ruminants, does not alter the appearance of $\left[{ }^{14} \mathrm{~N},{ }^{15} \mathrm{~N}\right]$ urea from ${ }^{15} \mathrm{NH}_{4} \mathrm{Cl}$ in sheep hepatocyte incubations (Lou et al. 1995).

Nissim et al. (1992) reported the synthesis of both $\left[{ }^{14} \mathrm{~N},{ }^{15} \mathrm{~N}\right]$ and $\left[{ }^{15} \mathrm{~N},{ }^{15} \mathrm{~N}\right]$ urea from ${ }^{15} \mathrm{~N}$-labelled amino acids in rat hepatocytes, but suggested that a lag in the increase in isotopic enrichment of $\left[{ }^{15} \mathrm{~N},{ }^{15} \mathrm{~N}\right]$ urea was due to flux through glutamate dehydrogenase. It is possible that during $\mathrm{NH}_{3}$ detoxification by ruminant liver in vivo, the equilibrium of glutamate dehydrogenase is also against the amination of 2-oxoglutarate and, thus, inhibits $\mathrm{NH}_{3}$ contribution to both $\mathrm{N}$ moities of the urea molecule. The equilibrium of this step will be determined in part by the mitochondrial redox state, and in sheep liver the concentrations of NADH and NADPH are lower on diets likely to increase $\mathrm{NH}_{3}$ supply to the liver (Prior et al. 1970). In rat mitochondrial preparations it has been proposed that $\mathrm{NH}_{3}$ inhibits the activity of citric acid cycle enzymes by causing a decrease in pyridine nucleotide levels (Katanuma et al. 1966), but the relevance of these results is unclear since an increase in hepatic $\mathrm{O}_{2}$ uptake has been reported during conditions of increased $\mathrm{NH}_{3}$ arrival at the liver (Wilton, 1989; Maltby et al. 1991). Calculations based on the maximum number of four ATP molecules hydrolysed for every mole of urea 
synthesized reveals that only $13 \%$ of the increased $\mathrm{O}_{2}$ uptake can be accounted for by urea synthesis, a value similar to that obtained by Reynolds et al. (1991). If the proposal that $\mathrm{NH}_{3}$ detoxification causes an increase in amino acid deamination is correct, then it would appear that amino acid-C skeletons are oxidized rather than used for gluconeogenesis.

\section{CONCLUSION}

The ability of the liver to detoxify $\mathrm{NH}_{3}$ to urea appears to be similar in ruminant and non-ruminant species, the principal difference being that the production of $\mathrm{NH}_{3}$ by foregut fermentation in ruminants is extremely variable and dependent on feed sources, whilst in non-ruminants, $\mathrm{NH}_{3}$ is produced in the hindgut and, therefore, absorption into the portal vein is affected far less by diurnal feed cycles. Despite the high rates of uptake from the gut which result from rapid fermentation of soluble $\mathrm{N}$ in forage diets, the ruminant liver is extremely adept at detoxifying $\mathrm{NH}_{3}$ to urea. However, there is evidence to suggest that $\mathrm{NH}_{3}$ detoxification to urea imposes a metabolic 'cost' in terms of amino acid deamination. This could explain observations of poor $\mathrm{N}$ retention in forage-fed ruminants, although further specific metabolic studies are required to identify a mechanism which could explain this interaction of $\mathrm{NH}_{3}$ with amino acid metabolism.

The authors gratefully acknowledge the help of Dr G. E. Lobley in the preparation of this review.

\section{REFERENCES}

Agricultural and Food Research Council (1993). Energy and Protein Requirements of Ruminants. Wallingford: CAB International.

Agricultural Research Council (1980). The Nutrient Requirements of Farm Livestock no. 2. Ruminants. Farnham Common: Commonwealth Agricultural Bureaux.

Agricultural Research Council (1984). Report of the Protein Group of the Agricultural Research Council Working Party on the Nutrient Requirements of Ruminants - Supplementary Report to Chapter 4 (ARC, 1980). Farnham Common: Commonwealth Agricultural Bureaux.

Aiello, R. J. \& Armentano, L. E. (1987). Gluconeogenesis in goat hepatocytes is affected by calcium, ammonia and other key metabolites but not primarily through redox state. Comparative Biochemistry and Physiology 88, 193-201.

Bergmeyer, H. U. \& Beutler, H. O. (1985). Ammonia. In Methods of Enzymatic Analysis, vol. 8, pp. 454-461 [H. U. Bergmeyer, editor-in-chief]. Basel: Weinheim.

Bödeker, D., Oppeliand, G. \& Höller, H. (1992a). Involvement of carbonic anhydrase in ammonia flux across rumen mucosa in vitro. Experimental Physiology 77, 517-519.

Bödeker, D., Shen, Y., Kemkowski, J. \& Höller, H. (1992b). Influence of short-chain fatty acids on ammonia absorption across the rumen wall in sheep. Experimental Physiology 77, 369-376.

Bödeker, D., Winkler, A. \& Höller, H. (1990). Ammonia absorption from the isolated reticulo-rumen in sheep. Experimental Physiology 75, 587-595.

Bryant, M. P. \& Robinson, I. M. (1962). Some nutritional characteristics of predominant culturable ruminal bacteria. Journal of Bacteriology 84, 605-614.

Chalupa, W. (1984). Discussion on protein symposium. Journal of Dairy Science 67, 1134-1146.

Cooper, A. J. L., Nieves, E., Coleman, A. E., Filc-DeRicco, S. \& Gelbard, A. S. (1987). Short-term metabolic fate of $\left[{ }^{13} \mathrm{~N}\right] \mathrm{ammonia}$ in rat liver in vivo. Journal of Biological Chemistry 262, 1073-1080.

Cotta, M. A. \& Hespell, R. B. (1986). Protein and amino acid metabolism of rumen bacteria. In Control of Digestion and Metabolism in Ruminants, pp. 122-136 [L. P. Milligan, W. L. Grovum and A. Dobson, editors]. Washington, DC: Butterworths. 
Demigné, C., Yacoub, C., Morand, C. \& Rémésy, C. (1991). Interactions between propionate and amino acid metabolism in isolated sheep hepatocytes. British Journal of Nutrition 65, 301-317.

Egan, A. R., Boda, K. \& Vardy, J. (1986). Regulation of nitrogen metabolism and recycling. In Control of Digestion and Metabolism in Ruminants, pp. 386-402 [L. P. Milligan, W. L. Grovum and A. Dobson, editors]. Washington, DC: Butterworths.

Fernandez, J. M., Croon, W. J., Tate, L. P. \& Johnson, A. D. (1990). Subclinical ammonia toxicity in steers: Effects on hepatic and portal-drained visceral flux of metabolites and regulatory hormones. Journal of Animal Science 68, 1726-1742.

Firkins, J. L., Lewis, S, M., Montgomery, L., Berger, L. L., Merchen, N. R. \& Fahey, G. C. (1987). Effects of feed intake and dietary urea concentration on ruminal dilution rate and efficiency of bacterial growth in steers. Journal of Dairy Science 70, 2312-2321.

Fitch, N. A., Gill, M., Lomax, M. A. \& Beever, D. E. (1989). Nitrogen and glucose metabolism by the liver of forage- and forage-concentrate fed cattle. Proceedings of the Nutrition Society 48, 76A.

Gross, K. L., Harmon, D. L. \& Avery, T. B. (1990). Portal-drained visceral flux of nutrients in lambs fed Alfalfa or maintained by total intragastric infusion. Journal of Animal Science 68, 214-221.

Harmon, D. L., Avery, T. B., Huntington, G. B. \& Reynolds, P. J. (1988). Influence of ionophore addition to roughage and high-concentrate diets on portal blood flow and net nutrient flux in cattle. Canadian Journal of Animal Science 68, 419-429.

Hartman, W. J. \& Prior, R. L. (1992). Dietary arginine deficiency alters flux of glutamine and urea cycle intermediates across the portal-drained viscera and liver of rats. Journal of Nutrition 122, 1472-1482.

Haussinger, D., Lamers, W. H. \& Moorman, A. F. M. (1992). Hepatocyte heterogeneity in the metabolism of amino acids and ammonia. Enzyme 46, 72-93.

Henning, P. H., Steyn, D. G. \& Meissner, H. H. (1993). Effect of synchronization of energy and nitrogen supply on ruminal characteristics and microbial growth. Journal of Animal Science 71, 2516-2528.

Hogan, J. P. (1961). The absorption of ammonia through the rumen of the sheep. Australian Journal of Biological Science 14, 448-460.

Hristov, M. \& Broderick, G. A. (1994). In vitro determinations of rumination protein degradability using $\left[{ }^{15} \mathrm{~N}\right]$ ammonia to correct for microbial nitrogen uptake. Journal of Animal Science 72, 1344-1354.

Huntington, G. B. (1984). Net absorption of glucose and nitrogenous compounds in lactating Holstein cows. Journal of Dairy Science 67, 1919-1927.

Huntington, G. B. (1989). Hepatic urea synthesis and site and rate of urea removal from blood of beef steers fed alfalfa hay or a high concentrate diet. Canadian Journal of Animal Science 69, 215-223.

Jungermann, K. (1986). Functional heterogeneity of periportal and perivenous hepatocytes. Enzyme 35, 161-180.

Kang-Meznarich, J. H. \& Broderick, G. A. (1981). Effects of incremental urea supplementation on ruminal ammonia concentration and bacterial protein formation. Journal of Animal Science 51, 422-431.

Katunuma, N., Okada, M. \& Nishi, Y. (1966). Regulation of the urea cycle and TCA cycle by ammonia. Advances in Enzyme Regulation 4, 317-336.

Kennedy, P. M., Early, R. J., Chrispherson, R. J. \& Milligan, L. P. (1986). Nitrogen transformations and duodenal amino acid content in sheep given four forage diets and exposed to warm and cold ambient temperatures. Canadian Journal of Animal Science 66, 951-957.

Kennedy, P. M. \& Milligan, L. P. (1978). Effects of cold exposure on digestion, microbial synthesis and nitrogen transformations in sheep. British Journal of Nutrition 39, 105-117.

Krebs, H. A., Lund, P. \& Stubbs, M. (1979). Interrelations between gluconeogenesis and urea synthesis. In Gluconeogenesis: Its Regulation in Mammalian Species, pp. 269-291 [W. Hanson and M. A. Melhan, editors]. New York: Wiley.

Linzell, J. L., Setchell, B. P. \& Lindsay, D. B. (1971). The isolated perfused liver of sheep: assessment of its metabolic, synthetic and secretory functions. Quarterly Journal of Experimental Physiology 56, 53-71.

Lobley, G. E. (1991). Some interactions between protein and energy in ruminant metabolism. In Proceedings of the 6th International Symposium on Protein Metabolism and Nutrition, Herning, Denmark, pp. 66-79 [B. O. Eggum, S. Boisen, C. Børsting, A. Danfær and T. Helplund, editors]. Foulum: National Institute of Animal Science.

Lobley, G. E., Connell, A., Lomax, M. A., Brown, D. S., Milne, E., Calder, A. G. \& Farningham, D. A. H. (1995). Hepatic detoxification of ammonia in the ovine liver: possible consequences for amino acid catabolism. British Journal of Nutrition 73, 667-685.

Luo, Q. J., Maltby, S. A., Lobley, G. E., Calder, A. G. \& Lomax, M. A. (1995). The effect of amino acids on the metabolic fate of ${ }^{15} \mathrm{NH}_{4} \mathrm{Cl}$ in isolated sheep hepatocytes. European Journal of Biochemistry 228, 912-917. 
McCullough, I. (1967). The determination of ammonia in whole blood by a direct colorimetric method. Clinica Chimica Acta 17, 297.

MacKie, R. I. \& White, B. A. (1990). Recent advances in rumen microbial ecology and metabolism: potential impact on nutrient impact. Journal of Dairy Science 73, 2971-2995.

MacRae, J. C. \& Reeds, P. J. (1980). Prediction of protein deposition in ruminants. In Protein Deposition in Animals, pp. 225-249 [P. J. Buttery and D. B. Lindsay, editors]. London: Butterworths.

MacRae, J. C. \& Ulyatt, M. J. (1974). Quantitative digestion of fresh herbage in sheep. II. The sites of digestion of some nitrogenous constituents. Journal of Agricultural Science, Cambridge 82, 309-319.

MacRae, J. C., Ulyatt, M. J., Pearce, P. D. \& Hendtlass, J. (1972). Quantitative intestinal digestion of nitrogen in sheep given formaldehyde-treated and untreated casein supplements. British Journal of Nutrition 27, 39-50.

Malmlöf, K. (1987). Porto-arterial plasma differences of urea and ammonia-nitrogen in growing pigs given high- and low-fibre diets. British Journal of Nutrition 57, 439-446.

Maltby, S. A., Beever, D. E., Lomax, M. A., Crompton, L. A. \& Pippard, C. J. (1993a). The influence of diet and increased ammonia supply on energy and nitrogen metabolism across splanchnic tissues in growing cattle. Animal Production 56, 431.

Maltby, S. A., Crompton, L. A., Lomax, M. A., Beever, D. E. \& Pippard, C. J. (1993b). The effect of increased ammonia supply on post-prandial hepatic metabolism in growing steers fed either forage or cereal-based diets. Proceedings of the Nutrition Society 52, $295 \mathrm{~A}$.

Maltby, S. A., Lomax, M. A., Beever, D. E. \& Pippard, C. J. (1991). The effect of increased ammonia supply on post-prandial portal-drained viscera and hepatic metabolism in growing steers fed maize silage. In Energy Metabolism of Farm Animals. European Association of Animal Production Publication no. 58, pp. 20-23 [C. Wenk and M. Boessinger, editors]. Zurich: ETH.

Maltby, S. A., Reynolds, C. K., Lomax, M. A. \& Beever, D. E. (1993c). The effect of increased absorption of ammonia and arginine on splanchnic metabolism of beef steers. Animal Production 56, 462-463.

Mathison, G. W. \& Milligan, L. P. (1971). Nitrogen metabolism in sheep. British Journal of Nutrition 25, 351-366.

Meijer, A. J., Lamers, W. H. \& Chamuleau, R. A. F. M. (1990). Nitrogen metabolism and ornithine cycle function. Physiological Reviews 70, 701-748.

Mooney, P. \& O'Donovan, D. J. (1970). The permeability of the rumen to simple nitrogenous compounds. Biochemical Journal 119, 18P-19P.

Nissim, I., Cattano, C., Nissim, I. \& Yudkoff, M. (1992). Relative role of the glutaminase, glutamate dehydrogenase and AMP-deaminase pathways in hepatic ureagenesis: studies with ${ }^{15} \mathrm{~N}$. Archives of Biochemistry and Biophysics 292, 393-401.

Nolan, J. V. (1975). Quantitative models of nitrogen metabolism in sheep. In Digestion and Metabolism in the Ruminant, pp. 416-431 [I. W. McDonald and A. C. I. Warner, editors]. Armidale: University of New England.

Nolan, J. V. \& MacRae, J. C. (1976). Absorption and recycling of nitrogenous compounds in the digestive tract of sheep. Proceedings of the Nutrition Society 35, 110A.

Nolan, J. V., Norton, B. W. \& Leng, R. A. (1976). Further studies on the dynamics of nitrogen metabolism in sheep. British Journal of Nutrition 35, 127-147.

Nolan, J. V. \& Strachin, S. (1979). Fermentation and nitrogen dynamics in Merino sheep given a low-quality-roughage diet. British Journal of Nutrition 42, 63-80.

Orzechowski, A., Motyl, T., Pierzynowski, G. \& Barej, W. (1987). Hepatic capacity for ammonia removal in sheep. Journal of Veterinary Medicine 34, 108-112.

Pilgrim, A. F., Gray, F. V., Weller, R. A. \& Belling, C. B. (1970). Synthesis of microbial protein from ammonia in the sheep's rumen and the proportions of dietary nitrogen converted to microbial nitrogen. British Journal of Nutrition 24, 589-598.

Prior, R. L., Clifford, A. J., Hogue, D. E. \& Visek, W. J. (1970). Enzymes and metabolites of intermediary metabolism in urea-fed sheep. Journal of Nutrition 100, 438-444.

Rémésy, C. \& Demigné, C. (1989). Specific effects of fermentable carbohydrates on blood urea flux and ammonia absorption in the rat cecum. Journal of Nutrition 119, 560-565.

Rémond, D., Chaise, J. P., Delval, E. \& Poncet, C. (1993a). Net flux of metabolites across the ruminal wall of sheep fed twice a day with Orchardgrass hay. Journal of Animal Science 71, 2529-2538.

Rémond, D., Chaise, J. P., Delval, E. \& Poncet, C. (1993b). Net transfer of urea and ammonia across the ruminal wall of sheep. Journal of Animal Science 71, 2785-2792.

Reynolds, C. K. (1992). Metabolism of nitrogenous compounds by ruminant liver. Journal of Nutrition 122 , $850-854$. 
Reynolds, C. K. \& Huntington, G. B. (1988). Partition of portal-drained visceral net flux in beef steers. 1. Blood flow and net flux of oxygen, glucose and nitrogenous compounds across stomach and post-stomach tissues. British Journal of Nutrition 60, 539-551.

Reynolds, C. K., Tyrell, H. F. \& Reynolds, P. J. (1991). Effect of diet forage-to-concentrate ratio and intake on energy metabolism in growing beef heifers: net nutrient metabolism by visceral tissues. Journal of Nutrition 121, 1004-1015.

Rooke, J. A., Lee, N. H. \& Armstrong, D. G. (1987). The effects of intraruminal infusions of urea, casein, glucose syrup and a mixture of casein and glucose syrup on nitrogen digestion in the rumen of cattle receiving grass-silage diets. British Journal of Nutrition 57, 89-98.

Satter, L. D. \& Slyter, L. L. (1974). Effect of ammonia concentration on rumen microbial protein production in vitro. British Journal of Nutrition 32, 199-208.

Seal, C. J., Parker, D. S. \& Avery, P. J. (1992). The effect of forage and forage-concentrate diets on rumen fermentation and metabolism of nutrients by the mesenteric- and portal-drained viscera in growing steers. British Journal of Nutrition 67, 355-370.

Seal, C. J. \& Reynolds, C. K. (1993). Nutritional implications of gastrointestinal and liver metabolism in ruminants. Nutrition Research Reviews 6, 185-208.

Siddons, R. C., Nolan, J. V., Beever, D. E. \& MacRae, J. C. (1985a). Nitrogen digestion and metabolism in sheep consuming diets containing contrasting forms and levels of N. British Journal of Nutrition 54, 175-187.

Siddons, R. C., Paradine, J., Gale, D. L. \& Evans, R. T. (1985b). Estimation of the degradability of dietary protein in the sheep rumen by in vivo and in vitro procedures. British Journal of Nutrition 54, 545-561.

Sinclair, L. A., Garnsworthy, P. C., Newbold, J. R. \& Buttery, P. J. (1993). Effect of synchronising the rate of dietary energy and nitrogen release on rumen fermentation and microbial protein synthesis in sheep. Journal of Agricultural Science, Cambridge 120, 251-263.

Song, M. K. \& Kennelly, J. J. (1989). Effects of ammoniated barley silage on ruminal fermentation, nitrogen supply to the small intestine, ruminal and whole tract digestion, and milk production of Holstein cows. Journal of Dairy Science 72, 2981-2990.

Spires, H. R. \& Clark, J. H. (1979). Effect of intra-ruminal urea administration on glucose metabolism in dairy steers. Journal of Nutrition 109, 1438-1447.

Symonds H. W., Mather, D. L. \& Collis, K. A. (1981). The maximum capacity of the liver of the adult dairy cow to metabolize ammonia. British Journal of Nutrition 46, 481-486.

Taminga, S. (1983). Recent advances in our knowledge on protein digestion and absorption in ruminants. In Protein Metabolism and Nutrition, Proceedings of the 4th EAAP International Symposium, pp. 263-287 [M. Arnal, R. Pion and D. Bonin, editors]. Paris: INRA.

Thompson, D. J., Beever, D. E., Lonsdale, C. R., Haines, M. J., Cammell, S. B. \& Austin, A. R. (1981). The digestion by cattle of grass silage made with formic acid and formic acid-formaldehyde. British Journal of Nutrition 46, 193-207.

van Berlo, C. L. H., van Leeuwen, P. A. M. \& Soeters, P. B. (1988). Porcine intestinal ammonia liberation. Influence of food intake, lactulose and neomycin treatment. Journal of Hepatology 7, 250-257.

Virtanen, A. I. (1969). On nitrogen metabolism in milking cows. Federation Proceedings 28, 232-240.

Visek, W. J. (1969). Some aspects of ammonia toxicity in animal cells. Journal of Dairy Science 51, $286-295$.

Visek, W. J. (1984). Ammonia: Its effects on biological systems, metabolic hormones and reproduction. Journal of Dairy Science 67, 481-498.

Weekes, T. E. C., Richardson, R. I. \& Geddes, N. (1978). The effect of ammonia on gluconeogenesis by isolated sheep liver cells. Proceedings of the Nutrition Society 38, 3A.

Weijs, P. J. M., Calder, A. G. \& Lobley, G. E. (1995). Incorporation of $\left[{ }^{15} \mathrm{~N}\right]$ ammonia into urea and amino acids as influenced by fasting and feeding. Proceedings of the Nutrition Society 54 (In the Press).

Wernli, C. G. \& Wilkins, R. J. (1980). Nutritional studies with sheep fed conserved ryegrass. 1. Silage and dried grass offered ad libitum without supplements. Quarterly Journal of Experimental Physiology 60 , 89-94.

Wilton, J. C. (1989). The effect of ammonia upon the metabolism of carbohydrates and amino acids in the liver of growing steers fed silage. PhD Thesis, University of Reading.

Wilton, J. C., Gill, M. \& Lomax, M. A. (1988). Uptake of ammonia across the liver of forage-fed cattle. Proceedings of the Nutrition Society 47, 153A.

Wolff, J. E., Bergman, E. N. \& Williams, H. H. (1972). Net metabolism of plasma amino acids by liver and portal-drained viscera of fed sheep. American Journal of Physiology 223, 438-446.

Wrong, O. (1978). Nitrogen metabolism in the gut. American Journal of Clinical Nutrition 31, 1587-1593. 
Yen, J. T. \& Nienaber, J. A. (1993). Effects of high-copper feeding on portal ammonia absorption and on oxygen consumption by portal-drained organs and whole animal in growing pigs. Journal of Animal Science 71, 2157-2163.

Yen, J. T. \& Pond, W. G. (1990). Effect of Carbadox on net absorption of ammonia and glucose into hepatic portal vein of growing pigs. Journal of Animal Science 68, 4236-4242. 